\title{
Features of the Norms of the Constitutional Law of Ukraine
}

\author{
ILLYA SHUTAK ${ }^{1}$, VITALII SKOMOROVSKYI ${ }^{2}$, GANNA MUZYCHENKO ${ }^{3}$, TETIANA RIABCHENKO ${ }^{4}$, \\ TATIANA KINZERSKA ${ }^{5}$, TETIANA HUMENIUK ${ }^{6}$ \\ ${ }^{1}$ Theory and History of State and Law Department, KING DANYLO UNIVERSITY, UKRAINE. \\ 2,5,6 State Legal Department, "KROK" UNIVERSITY, UKRAINE. \\ ${ }^{3}$ Political Sciences and Law Department, SOUTH UKRAINIAN NATIONAL PEDAGOGICAL UNIVERSITY NAMED \\ AFTER K. D. USHYNSKY. UKRAINE. \\ ${ }^{4}$ Constitutional Law, Theory and History of State and Law Department, SUMY STATE UNIVERSITY. UKRAINE. \\ E-mail: ttt-kry@ukr.net
}

\begin{abstract}
The article is devoted to the study of the peculiarities of the norms of the constitutional law of Ukraine. The authors analyzed some issues of the theory of norms of the constitutional law of Ukraine, features of its legal (normative) nature, the genesis of norms of the constitutional law of Ukraine. Investigated the essence of the Constitution and the direct effect of the Constitution of Ukraine. The legal peculiarities of the norms of the constitutional law in the material and procedural aspects were singled out. They provided a classification of constitutional and statutory norms and their legal features. Demonstrated the unconventional structure of the norm of constitutional law.
\end{abstract}

Keywords: Constitution, Constitutional law, norms, Ukraine.

JEL Classification: K10, K19, K39

Received: 28 March 2021

Accepted: 30 April 2021 


\section{Introduction.}

In studying the problem of the peculiarities of the norms of the constitutional law of Ukraine, it is noteworthy that in the scientific literature there is a debatable issue regarding the definition of constitutional law and the problem of legal (normative) nature of the constitutional norm becomes important.

The authors were analyzing the norms of constitutional law, their classification, structure, the content of direct action through the scientific works of such scientists as Barsky V. [1], llyenko L. [2], Kostsova I. [3], Krusyan A. [4], Letnyanchyn L. [5], Makarenko L. [6-7], Melnyk M. [8], Oliynyk A. [9], Onishchenko O. [10-11], Podtserkovny O. [12], Shevchuk I. [13], Sinkevych O. [14-15], Skrypniuk O. [16], Stepanyuk O. [17], Todyka Yu. [18], Yarmysh O. [19] and others see the exclusivity and individuality of the norms of constitutional law, which markedly distinguishes the latter from the norms of other branches of law.

Knowledge of this issue will avoid many negative trends that occur in political and legal reality. Ukrainian constitutionalism is in the process of registration, and therefore the appeal of scholars to the theoretical problems of constitutional law is relevant and natural.

\section{Some Questions of the Theory of Norms of the Constitutional Law of Ukraine, Features of Its Legal (Normative) Nature, Genesis of Norms of the Constitutional Law of Ukraine.}

The authors of modern works in the field of the constitutional law of Ukraine understand the constitutional and legal norms established or sanctioned by the state rules that determine the behaviour of participants in constitutional and statutory relations in the exercise of sovereignty of the people of Ukraine. Thus, the norms of constitutional law by analogy with the norms of other branches of law are traditionally defined as specific rules that govern the behaviour of the parties to the legal relationship. This naturally presupposes the enshrinement by these legal norms of the relevant rights and obligations of the subjects of constitutional legal relations.

According to the modern Ukrainian scientist $O$. Stepanyuk, the norm of constitutional law is a rule adopted by the legislature, and sometimes by the judiciary and the executive, which indirectly through human behaviour regulates political relations that arise in the organization and exercise of public power, as well as ties with citizens [17]. Another scholar L. Makarenko disagrees with this definition of the norm of constitutional law, characterizes this approach is more typical of the norms of the so-called private branches of law - civil, family, labour, etc., because its subjects are primarily citizens of Ukraine, foreigners, stateless persons, i.e. individuals. The questions of constitutional and legal relations, along with the above categories of individuals are often the relevant public authorities, as well as particular communities, which should include both the Ukrainian people as a whole and individual communities of citizens represented by national minorities, territorial communities, etc. [7].

At the same time, not all constitutional and legal norms establish precisely defined rights and obligations of the participants of the relations regulated by the norms. One of the features of constitutional law is precisely the presence among its provisions of those that do not seem to fall under the model of rules of conduct entirely but are still considered legal provisions. Many such arrangements are provided in particular in the preamble and the first section of the Constitution of Ukraine, as well as in the prefaces and general provisions of laws establishing general principles, tasks and purpose of legal regulation (Rules of Procedure of the Verkhovna Rada of Ukraine, etc.).

In this regard, the position of some scholars is based on the fact that norms that do not specifically regulate the behaviour of individuals but have the character of starting points, can not be recognized by law, and that certain constitutional provisions become legal relations only by other legal norms and only in combination with them [6].

Many constitutional norms have an authoritative public-law character, more often determine the activities of public authorities and local self-government, rather than individual behaviour. Unlike 
other branches of law, the norms of constitutional law have much more provisions of a general regulatory nature. These, first of all, include norms - principles, norms - concepts, norms - tasks, many of which are in the first chapter of the Constitution of Ukraine and the implementation of which is not related to the emergence of specific legal relations, but general relationships or certain legal statuses. Their task is not to define the rights and responsibilities of the subjects, but otherwise to be a link between the norms of other branches of law, and integrating factor that ensures the unity and stability of the legal system of Ukraine [3].

The normative nature of most norms of constitutional law is not in doubt and is not denied in the literature. However, it is more challenging to deal with those articles of the constitutional law that formulate the tasks of the state, declarations and historical references or goals that the legislator has in mind.

There is also this view: there are articles that are descriptive or ascertaining, not normative. They have world-historical significance, but do not contain any specific rules of conduct and are not intended to apply to any particular legal relationship. Even though these provisions are expressed in regulations of great historical significance, but they are not normative in nature. The above gives grounds to conclude: there is no unity of views on the authoritative nature of constitutional - legal norms, and hence - their different understanding [11].

How can we consider specific articles of the Constitution of Ukraine that, for example, establish a constitutional order? Accurate, they do not provide options for the behaviour of the subjects, but this does not diminish their importance in legal regulation. These are individual legal attitudes, guiding principles, which are nothing but norms of law because the term "norm" translated from Latin means not only a rule but also a guiding principle, a pattern. In fact, many norms of the Constitution, based on their constitutive nature, are the guiding ones, and they are disclosed and detailed in the norms of other branches of law. The Basic Law of Ukraine establishes such prescriptions that cover all significant phenomena of society and limits them to a certain framework - standards. State authorities and local self-government bodies, officials, citizens and other subjects of constitutional and legal relations are obliged to be guided in these activities by these provisions and definitions.

It is undeniable that the preambles of the constitutions, historical references, the wording of the tasks of the state also have normative properties. However, they do not formulate certain rights and responsibilities. The political meaning here has a normative meaning in the sense that they legally oblige state bodies and officials to adhere to its goals and objectives, always to express the interests and will of the people [15].

The norms of the constitutional law of Ukraine have deep genetic roots, as, for example, the institutions of separation of powers, self-government, local administration, etc. were known since the princely era. Still, it can not be said that even then there was a national constitutional law. The opinion is substantiated that the act that initiated the constitutional law of Ukraine was the IV Universal of the Ukrainian Central Rada (1918) [12;14].

It is seen that the modern interpretation of constitutional and legal norms should be based on the category of "interest". Therefore, the position that the genetic origin of the norms of the constitutional law of Ukraine is taken in specific public interests of social groups is substantiated. Constitutional and legal norms are accepted as a mutual interest of such groups as a result of social consensus, compromise. That is, it is proved that the modern constitutional law of Ukraine is applied on a contractual basis, and not on the unilateral will of a particular social group [16].

\section{The Essence of the Constitution. Direct Effect of the Norms of the Constitution of Ukraine.}

Any constitution as a document is a legal normative-legal act of higher legal force, which contains norms of law that have different aspects and is characterized from different positions: philosophical, psychological, pedagogical, social and others, which are characterized depending on who analyzes and depending on the peculiarities of the sphere of public relations. Scientist L. Makarenko describes 
the Constitution in its essence as a normative-legal agreement, and in its form - a normative-legal act in the form of the Basic Law of the state, which defines or should reflect the social needs and interests of the majority of the people of Ukraine (or the whole people), important principles (ideas, patterns, bases) and norms that consolidate the political, economic, social and legal development of the state and society in the modern period and shortly [8].

The Constitution as the Basic Law of the state has all the features of a normative - legal act: it is formally defined, has a general obligation for all subjects of public relations, protection of its norms, principles and provisions from offences is carried out specially, it guarantees protection of social values, which consolidates and proclaims. The Constitution contains different rules of law: legal, dispositive, imperative (state - authoritative), authorizing, binding, prohibiting.

The Constitution of Ukraine is a form of expression of constitutional and legal norms. In analyzing the Constitution, scientist $\mathrm{O}$. Stepanyuk emphasizes the following provisions:

1. The Constitution is the highest legal act. It consolidates the organization of bodies exercising public power based on the principle of people's sovereignty, their relationship between themselves and citizens.

2. It must be a legal expression of the restriction of state power.

3. The Constitution is an element of the system of normative acts. It is not outside the scope of existing law, is an integral part of national law, and at the same time - a specific piece of legislation. Moreover, it is the main branch of national law and the entire legal system of Ukraine.

4. It contains norms of exclusively constitutional law, which at the same time, can be the basis of branch legal norms [17].

Article 8 of the Constitution of Ukraine establishes that the norms of the Constitution are norms of direct action.

In the legal literature, the direct effect of the norms of the Constitution of Ukraine is considered as its legal property. However, there are different approaches to understanding the meaning of this concept. According to M. Baglay, the Constitution is a part of constitutional law. Each norm of the Basic Law is overgrown with other norms from different branches of law, which creates the danger of dissolving legal provisions in the sea of constitutional law, losing their priority. That is why the legislator gives the requirements of the Constitution direct effect. This allows the interested party to demand protection of his rights in court by referring only to the constitutional wording.

V. Kravchenko also defines the direct effect of the norms of the Constitution of Ukraine as the possibility of going to court to protect the constitutional rights and freedoms of man and citizen directly based on the Constitution of Ukraine. However, such an understanding of the direct effect of the norms of the Constitution of Ukraine seems somewhat limited, as the direct impact makes it possible to apply directly based on the Constitution of Ukraine not only to the court but also to any entity authorized to apply constitutional norms [10]. We must agree with the opinion of V. Shapoval, who writes that the provision on the direct effect of the Constitution of Ukraine primarily means that all public authorities and their officials in their law enforcement activities should not just focus on constitutional norms, but adopt relevant decisions directly on the basis and content of these norms [2].

It should be noted that the content of the direct effect of the Constitution of Ukraine (Fig. 1). 
Figure 1. The content of the direct effect of the Constitution of Ukraine

\begin{tabular}{|l}
$\longrightarrow$ \\
$\qquad \begin{array}{l}\text { THE DIRECT EFFECT OF THE CONSTITUTION OF UKRAINE } \\
\text { as the effect of the Constitution of Ukraine, regardless of the existence of } \\
\text { regulations that specify or supplement it; }\end{array}$ \\
$\begin{array}{l}\text { the right of a citizen to demand from any subject and vice versa the } \\
\text { implementation of such a rule (instruction); }\end{array}$ \\
$\begin{array}{l}\text { publication of laws that specify the provisions of the Constitution, including } \\
\text { those specified in the text of the Basic Law of Ukraine. }\end{array}$
\end{tabular}

The direct effect of all constitutional norms, as pointed out by Yu. Tikhomirov, means, first, that they all come into force at once, because each norm acts in the system of the Constitution as its element. Secondly, there is no general rule and procedure for suspending or postponing the implementation of specific rules.

According to Yu. Todyka, when applying constitutional norms there is no sense or need to oppose the direct and indirect form of its implementation, as most often the norms of the Constitution of Ukraine are applied together with the norms of various branches of law. That is, the direct and indirect effect of the norms of the Constitution should be considered as components of the direct impact of the constitutional norms. As for indirect action, it can be carried out after the specification of the Constitution and other legislative acts. Such a constitution is ensured by the norms of different branches of law [19].

And the fact that the provisions of the Constitution are implemented in different ways: independently, without any other legal requirements, or through acts of current legislation together with their provisions, does not contradict the fact that the provisions of the Constitution are the rules of direct action. This fact only indicates the peculiarities of the implementation of its regulations.

There are two aspects of the direct effect of the Constitution: legislative and law enforcement. In the legislative sense, its direct effect means that laws are issued to implement the norms of the Constitution, including those provided for in the text of the Constitution. According to Yu. Todyka, if the current legislation is based on the democratic principles enshrined in the Constitution of Ukraine, it has a positive effect on the entirely legal system. In this case, we can talk about the direct effect of the Constitution [19].

Another significance of the direct effect of the Constitution is the use of constitutional norms by law enforcement agencies. However, it should be noted that this is not always possible, as in some cases the provisions of the Constitution require additional regulation. This applies, for example, to the rules on citizenship, entrepreneurship, elections, and so on. Without additional laws, such norms are difficult to implement.

Finally, due to the direct effect of its norms, the Constitution always remains a real part of permanent law, which gives every reason to define it not just as a formal Basic Law, but as a real part of the legal system and legal system that can and should be applied daily in legal practice. The characteristic features of the Constitution of Ukraine as the primary source of constitutional law include those that the Constitution is adopted and enters into force in accordance with a particular procedure provided by law. A special method is provided for amendments to the Constitution of Ukraine.

Based on the above analysis, we can draw the following conclusions: the direct effect of the Constitution of Ukraine is its legal property, which has a fairly broad meaning, which includes three 
components. First, the effect of the Constitution of Ukraine, regardless of the existence of regulations that specify or supplement it; secondly, the right of a citizen to demand from any subject authorized to apply constitutional norms, to enable him to use the norm included in the text of the Constitution, and the obligation of the obligated subject to comply with such a requirement of a citizen; thirdly, the publication of laws that specify the provisions of the Constitution, including those specified in the text of the Basic Law of Ukraine.

Negatively affects the direct application of constitutional norms of perception of the Basic Law as a declarative act. Therefore, it is important to increase the legal culture of public authorities and their officials regarding the direct effect of the Constitution of Ukraine. The latter must, through the conscious application of the norms of the Basic Law to specific life situations, root in the legal consciousness of citizens the role of the Constitution of Ukraine as a direct act.

\section{Legal Features of the Norms of Constitutional Law in Substantive and Procedural Aspects.}

Following the provisions of the Constitution of Ukraine, the requirements of the Basic Law are endowed with the legal property of direct action, the essence of which is set out in the previous section of this article.

In modern jurisprudence, there are practically no scientific researches which would outline the theoretical and methodological substantiation of reasonable prospects of use of the legal property of direct action of norms of the Constitution of Ukraine in material and procedural aspects.

It should be noted that the procedural aspect of the direct effect of the Constitution of Ukraine is not independent of the substantive aspect - the implementation of provisions providing for the adoption of special laws is impossible without the existence of a direct rule. That is, the procedural aspect of the direct effect of the norms of the Constitution is derived from the material aspect [6].

Thus, Part 1 of Art. 44 of the Constitution of Ukraine guarantees the right to strike to anyone who works to protect their economic and social interests. Part 2 of Art. 44 of the Constitution of Ukraine stipulates that the procedure for exercising the right to strike is established by law, taking into account the need to ensure national security, health care, rights and freedoms of others.

Thus, the primary rule, in this case, is Part 1 of Art. 44 of the Constitution of Ukraine. To exercise the right to strike in the text of Part 2 of Art. 44 of the Constitution of Ukraine states on the regulation of the procedure for applying such a power by a special law and sets out the requirements for the following process: ensuring national security, health care, rights and freedoms of others.

No matter how perfect the constitutional and legal norms look, they are worthless if there is no mechanism for their implementation. It is the procedural norms of constitutional law that ensure the functioning of the rights and obligations of the subjects of legal relations, establish the mechanism of implementation of substantive norms, but their allocation to a separate branch of law is impractical and impossible. This is due to their interpenetration.

Procedural norms of the constitutional law of Ukraine are characterized by the following branch features (Fig. 2) [2].

Procedural norms of constitutional law are widely represented in the Constitution of Ukraine. These include norms that establish: the procedure for electing the President of Ukraine and the procedure for exercising his powers; the procedure for removing the President of Ukraine from office by the Verkhovna Rada of Ukraine; the procedure for the formation and operation of the Verkhovna Rada of Ukraine (including the procedure for the preparation and adoption of laws); procedure for early termination of powers of the Verkhovna Rada of Ukraine and others.

The provisions of the Constitution of Ukraine are subject to direct implementation in two aspects - substantive and procedural. The material element consists of the full extension of the relevant norms of the Constitution of Ukraine to legal relations and excludes the need to apply other legislative acts. The procedural aspect of the direct effect of the norms of the Constitution of Ukraine can be traced in the instructions that contain references to special laws. 


\section{Some Criteria of Classification of Constitutional-Legal Norms, Their Legal Signs. Unconventional Structure of the Norm of Constitutional Law.}

Thus, the norm of the constitutional law of Ukraine is a rule of conduct or activity that is formally defined, established or sanctioned by the Ukrainian people, the Ukrainian state, territorial communities and other subjects of constitutional and legal relations, which regulates public relations that are the subject of constitutional law, constitutional guarantees. Peculiarities of the norms of the constitutional law of Ukraine can be divided into two groups (Fig. 3) [17; 20].

It should also be noted that the political nature of constitutional norms cannot be the basis for characterizing them as political norms. The very fact of objectification of these norms in constitutional and legal normative acts is evidence of their licensed content. By adopting them, the rule-making body sought to achieve inevitable legal consequences. They give rise to the respective legal obligations imposed on the subjects of constitutional law and the granting of rights to them. In some cases, they are protected by state coercion. These norms are adopted in relation to policy, but not in its formal expression. Of course, political relations are also regulated by political norms, but they remain outside constitutional law. However, there is no denying the cases when political norms can be given the status of constitutional and legal.

Analysis of the forms of expression of constitutional law gives grounds to characterize the constitutional - legal regulation in Ukraine as quite strict. It is carried out only by means provided by the constitutional legislation. Although the development of events forces us to pay attention to the real possibility of creating soon constitutional and legal precedents and customs. According to the form of expression, the subject of legal regulation can be distinguished imperative and dispositive norms of constitutional law.

Imperative norms of the constitutional law of Ukraine are absolutely strict norms that provide a single variant of lawful behaviour by the subjects of constitutional law. An example of such a rule can be Art. 74 of the Constitution of Ukraine "Referendum is not allowed on bills on taxes, budget and amnesty." Dispositive norms of constitutional law are norms that determine the possibility of choosing the right option of behaviour by the subjects of constitutional law. For example: "AllUkrainian referendum is appointed by the Verkhovna Rada of Ukraine or the President of Ukraine following their powers established by this Constitution" (Part 1 of Article 72 of the Constitution of Ukraine).

The following classification of constitutional legal norms can be offered (Fig. 4).

At one time, at the beginning of the last century, the famous jurist M. Korkunov in his work "Lectures on the general theory of law" wrote "... all legal norms are conditional rules. Therefore, each legal norm, of course, consists of two elements: the definition of the conditions of application of the rule and the statement of the rule itself. The first element is called a hypothesis or prediction; the second - by disposition or order. Each legal norm can be expressed in the form: if - then... ". And he considered sanctions of legal norms "means of coercion to comply with legal norms.

Referring to the current constitutional legislation of Ukraine, the opinion is expressed that the peculiarity is that in most cases these norms have only a disposition, i.e. certain rules of conduct. There are norms consisting of a hypothesis - nature - sanctions or a hypothesis-disposition, or only disposition. A variant of the "disposition-sanction" structure can also be reduced to such a scheme.

The peculiarity of the structure of a constitutional norm is that not every such norm can be objectively three-membered, first of all, regulatory and protective norms, while most norms of constitutional law have a constitutive character and do not have sanctions or hypotheses; elements of the constitutional and legal norm are very difficult to single out in the concrete - objectified norm of the law as the hypothesis and dispositions are intertwined and "merge" into a single whole; sanctions of constitutional law have a preventive and educational purpose. 
Illya Shutak, Vitalii Skomorovskyi, Ganna Muzychenko, Tetiana Riabchenko, Tatiana Kinzerska, Tetiana Humeniuk

Figure 2. Characteristics of sectoral features of procedural norms of the constitutional law of Ukraine

SECTORAL FEATURES OF PROCEDURAL NORMS OF THE CONSTITUTIONAL LAW OF UKRAINE

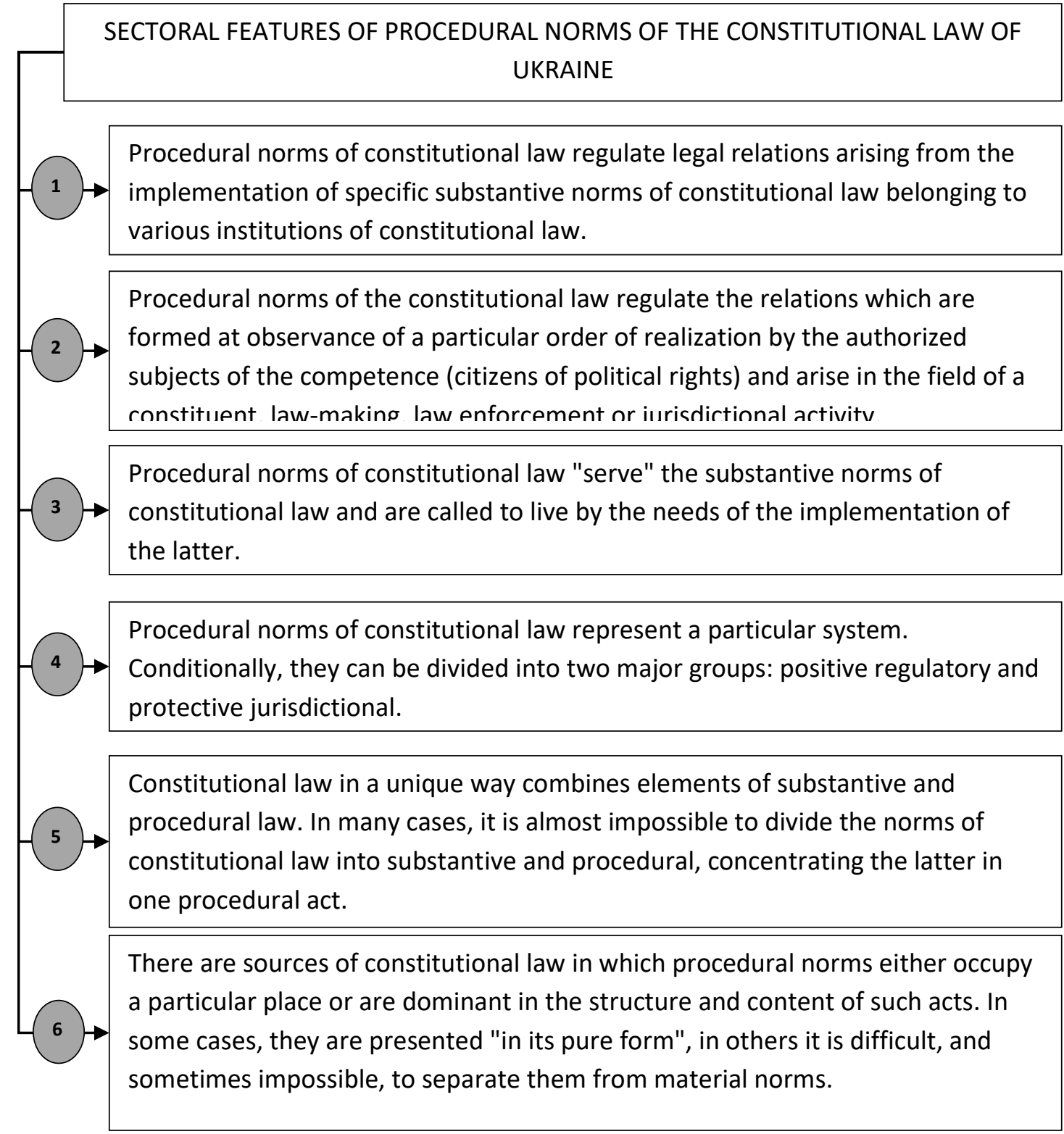

There is an opinion that sanctions of the constitutional law are connected with retrospective responsibility and consist in a negative state and legal assessment of illegal behaviour and with the occurrence of adverse consequences for subjects of constitutional and statutory relations: impeachment of the President of Ukraine, dissolution of the Verkhovna Rada, the resignation of the Cabinet of Ministers of Ukraine in case the parliament of Ukraine adopts a resolution of no confidence in the government [14].

The nature of the expression in the norms of constitutional law prescriptions allows us to talk about norms-principles, norms of definition, fundamental norms, regulatory and protective constitutional-legal norms. The norms of constitutional law may apply on the entire territory of Ukraine, on a particular territory of Ukraine and abroad. Depending on the bodies that adopt the norms of this branch of law, they are divided into the norms adopted by the All-Ukrainian referendum, the parliament, the Constitutional Court, and the President. 
Figure 3. Characteristics of general and special features of the norms of the constitutional law of Ukraine

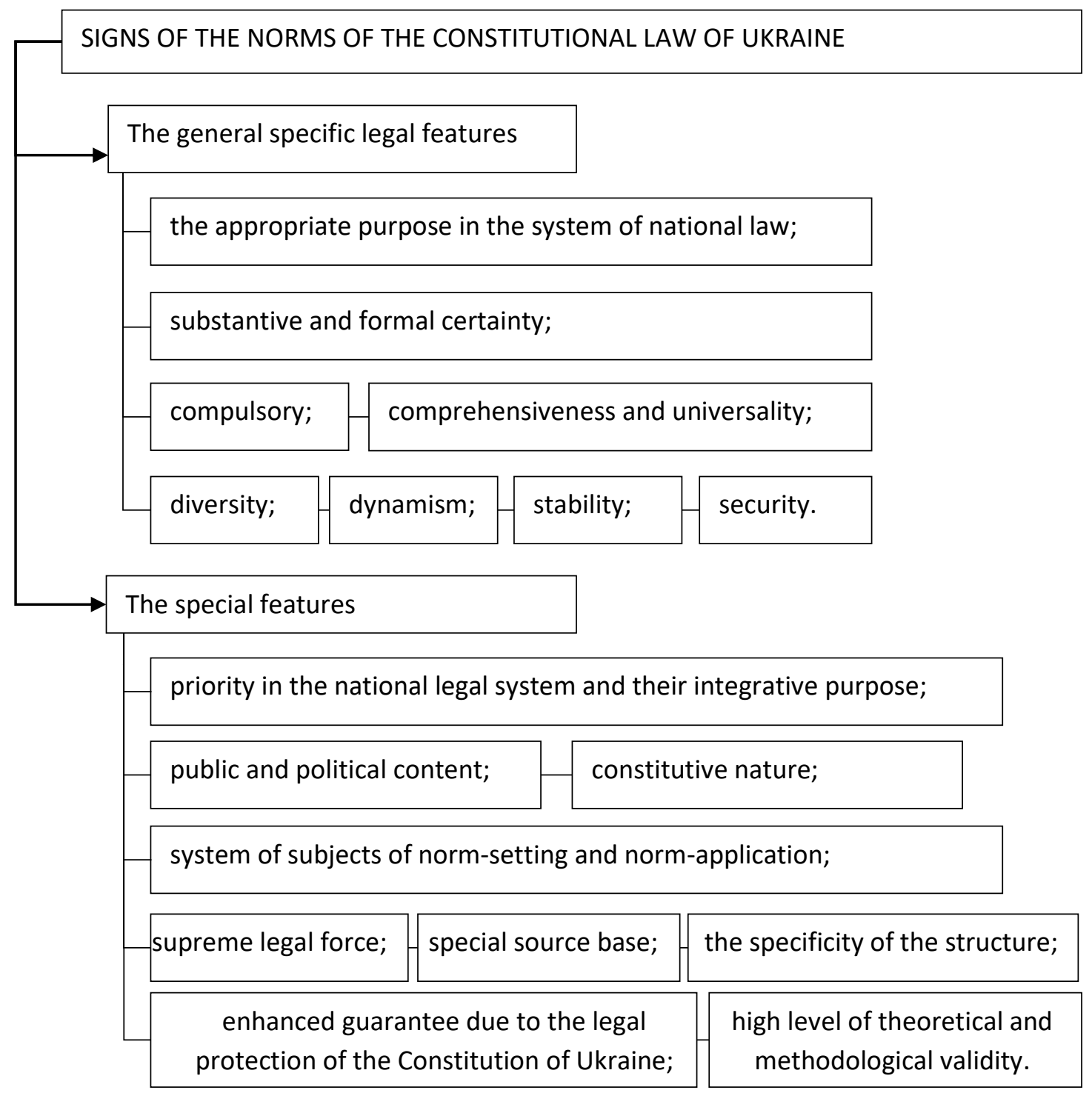

The justification of the question of codification of constitutional and legal norms is substantiated. After all, only codification concerns the law-making process, which deals with constitutional and legal norms. Codification of the norms of constitutional law can be considered as a type of law-making. Codification is possible when the accumulated normative-legal, scientific material and material of practical approbation of norms $[5 ; 9]$. 
Figure 4. Classifications of constitutional and legal norms

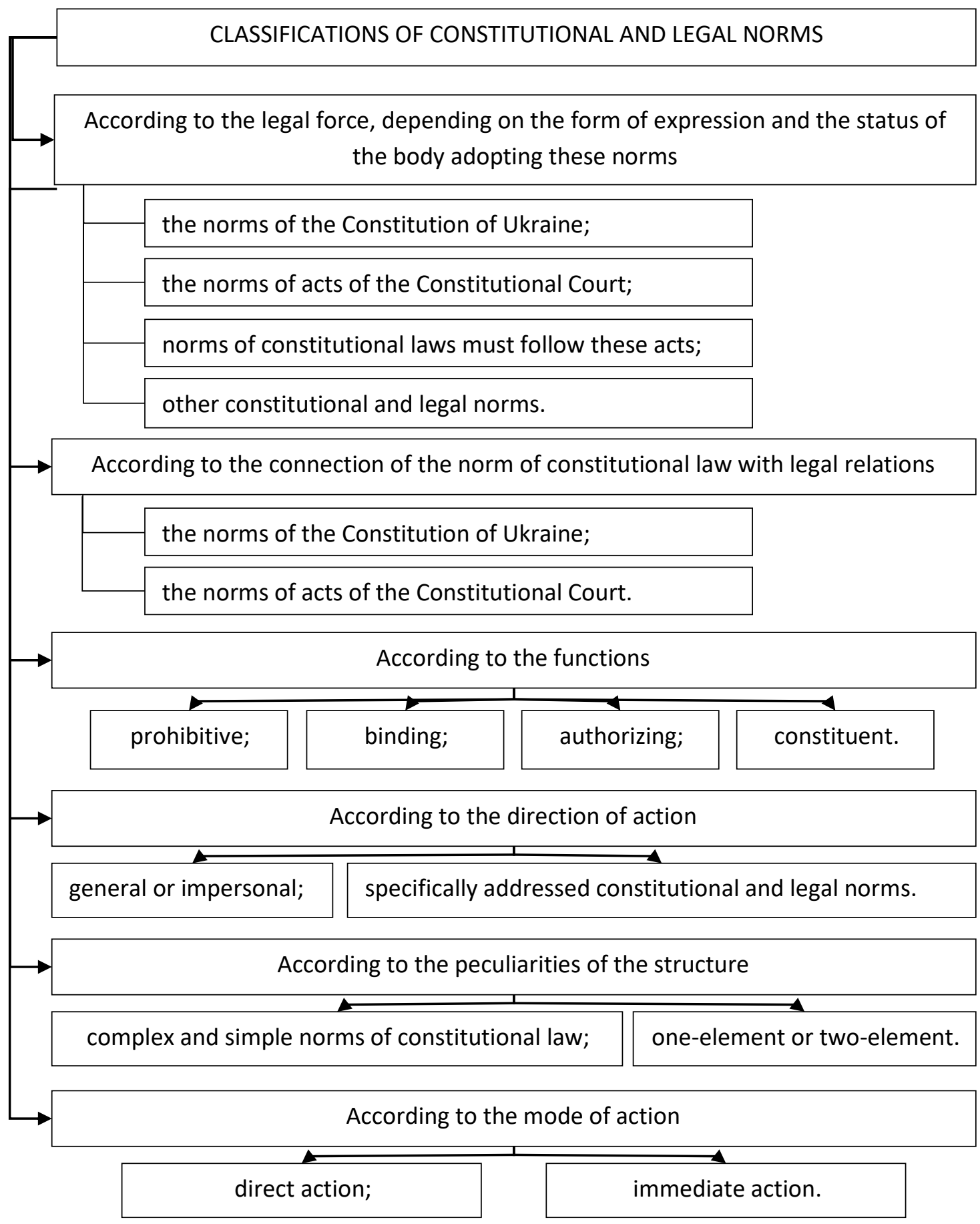

\section{Conclusion.}

Thus, the peculiarity of the norms of the constitutional law of Ukraine is that the latter do not always regulate the rule of conduct of the subjects of constitutional and legal relations. First of all, these are norms - instructions, starting points that establish the general principles, tasks and purpose of legal regulation.

Unlike other norms of branches of law, the norms of constitutional law have more provisions of a general regulatory nature. 
Constitutional norms are norms - restrictions on state power. They act as a guarantee against abuse of power by some authorities and other bodies.

Analyzing such a feature of the norms of the constitutional law of Ukraine as a direct effect of the Constitution, he concluded that the perception of the Basic Law only as a declarative act negatively affects the direct application of constitutional norms. Therefore, it is vital to increase the legal culture of public authorities and their officials regarding the direct effect of the Constitution of Ukraine. The latter must, through the conscious application of the norms of the Basic Law of Ukraine to specific life situations, root in the legal consciousness of citizens the role of the Constitution as a direct act.

\section{References}

1. Barsky V. Procedural norms of constitutional law, Legal life of modern Ukraine: materials of the International. Science. conf. prof.-off and graduate student, 2011.

2. Ilyenko L. An effective tool to ensure the implementation of the Constitution. Legal Bulletin of Ukraine, 2006, 24-25, P. 8

3. Kostsova I. Systemic method of interpretation of legal norms: a feature of the constitutional and legal status. Bulletin of the Ministry of Justice of Ukraine, 2016, No 1.

4. Krusyan A. Constitution and constitutional legislation as a normative basis of modern Ukrainian constitutionalism. Legal Bulletin, 2005, No. 1, pp. 88-96.

5. Letnyanchyn L. Direct action of the norms of the Constitution of Ukraine: from principle to practical application. Bulletin of the National Academy of Legal Sciences of Ukraine, 2017, No. 4 (91).

6. Makarenko L. Peculiarities of the norms and principles of the Constitution of Ukraine. State and law, 2000, No. 8, pp. 3-8

7. Makarenko L. Some issues of the theory of norms of constitutional law of Ukraine. State and law, 2001, No. 12, pp. 197-201.

8. Melnyk M. On the boundaries of constitutional jurisdiction and the direct effect of the Constitution of Ukraine in the administration of justice. Bulletin of the Constitutional Court of Ukraine, 2016, No 4/5.

9. Oliynyk A. International standards and constitutional norms in the regulation of constitutional freedoms of man and citizen in Ukraine. Scientific Bulletin of Dnipropetrovsk State University of Internal Affairs, 2010, No. 1 (47)

10.Onishchenko O. Direct effect of the Constitution of Ukraine. Entrepreneurship, Economy and Law, 2004, No. 5, pp.90-93.

11.Onishchenko $\mathrm{O}$. The role of the official interpretation of the Constitution of Ukraine in its implementation. Bulletin of the Khmelnytsky Institute of Regional Management and Law: Coll. Science. works on the materials of the International. Science. conf. students and graduate students "Actual problems of jurisprudence through the eyes of young scientists, 2002, N1, pp. 57-58.

12.Podtserkovny O. On the problems of direct effect of constitutional provisions (on the example of compensation at the expense of the state). Legal Bulletin, 2015, No. 3.

13.Shevchuk I. Features of sanctions of constitutional law, Development of statehood and law in Ukraine: realities and prospects. Proceedings of the 1st International Scientific and Practical Conference (April 24, 2009), pp. 153-156.

14.Sinkevych O. Peculiarities of the structure of the norms of the constitutional law of Ukraine. Journal of Kyiv University of Law, 2003, No 4

15.Sinkevych O. On the peculiarities of the constitutional law of Ukraine. Law of Ukraine: Jurid. Journal, 2002, No. 11, pp. 15-18. 
16.Skrypniuk O. Universality of the Constitution of Ukraine as a source of law. Bulletin of the National Academy of the Prosecutor's Office of Ukraine, 2010, No 4, pp. 35-39.

17.Stepanyuk O. Norms of constitutional law of Ukraine: problems of theory. Author's ref. dis. Cand. jurid. Science, Kyiv, 1993.

18.Todyka Yu. Procedural norms in the constitutional law of Ukraine. Problems of legality, 2006, No. 77, pp. 3-9.

19.Yarmysh O. Temporal action of constitutional and legal norms: problems of theory and practice. Bulletin of the Academy of Legal Sciences of Ukraine, 2010, No. 3. 